\title{
Strategi Pengawasan Siaran Televisi Lokal Oleh Komisi Penyiaran Daerah
}

\author{
Windarto $^{1}$, Eko Nuriyatman², Rustian Mushawirya ${ }^{3}$ \\ ${ }^{1,2,3}$ Fakultas Hukum Universitas Jambi, Indonesia \\ Perum Bambu Apung 2, Blok B.06, Desa Sungai Duren, Blok B.06, Kecamatan Jambi Luar Kota, Indonesia \\ Correspondance email: mas_wiend@unja.ac.id, email: ekonuriyatman90@gmail.com, email: mushawirya@gmail.com
}

\begin{abstract}
Abstrak. Artikel ilmiah ini mebahas mengenai strategi pengawasan siaran televisi lokal oleh komisi penyiaran daerah Provinsi Jambi. Metode penelitian yang digunakan adalah yuridis empiris untuk dapat menemukan jawaban mengenai bagaimanakah kondisi siaran televisi lokal di Provinsi Jambi dan mengenai strategi pengawasan yang dilakukan oleh komisi penyiaran daerah. Berdasarkan hasil penelitian di dapatkan data bahwa banyak terdapat pelanggaran terutama pada saat pelaksanaan pemilihan kepala daerah dan terdapat 12 (dua belas) pelanggaran yang telah diberikan sanksi teguran, pelanggaran yang terjadi tersebut merata pada semua program baik iklan, berita dan cinema. Strategi pengawasan siaran televisi dengan melakukan monitoring siaran dan mendapat laporan dari masyarakat. Teori yang digunakan di dalam artikel ilmiah ini adalah teori efektifitas hukum yang mana meninjau dari keberhasilan dalam pelaksanaan hukum, kegagalan dalam pelaksanaan dan faktor yang mempengaruhi. Karena dalam hal ini keberhasilan dalam pelaksanaan hukum pada artikel ilmiah ini adalah dipatuhi oleh lembaga penyiaran yang terkena sanksi. Sedangkan untuk televisi lokal yang berada di Luar Kota Jambi dilakukan dengan strategi membentuk relawan pengawas yang berada pada masing-masing kabupaten/kota yang terdapat televisi lokal.
\end{abstract}

Kata Kunci: Pengawasan; Strategi; Komisi Penyiaran Daerah.

\begin{abstract}
This scientific article discusses the strategy of monitoring local television broadcasts by the regional broadcasting commission of Jambi Province. The research method used is juridical empirical to be able to find answers about how the local television broadcast conditions in Jambi Province and the monitoring strategy carried out by the regional broadcasting commission. Based on the research results, data shows that there are many violations, especially during the implementation of regional head elections and there are 12 (twelve) violations that have been given a reprimand sanction, the violations that occur are evenly distributed in all programs both advertising, news and cinema. Television broadcast surveillance strategy by monitoring broadcasts and receiving reports from the public. The theory used in this scientific article is the theory of legal effectiveness which reviews the success in implementing the law, failure in implementation and the factors that influence it. Because in this case the success in implementing the law on this scientific article is obeyed by the broadcasting institutions that are subject to sanctions. As for local television located outside Jambi City, the strategy was to form volunteer supervisors located in each district / city where local television was available.
\end{abstract}

Keywords: Supervision; Strategy; Regional Broadcasting Commission.

\section{PENDAHULUAN}

Perkembangan media yang sangat pesat saat ini terutama dalam dunia pertelevisian tentu akan menimbulkan dampak positif dan dampak negatif terhadap sosial budaya masyarakat yang ada saat ini, maka pemerintah harus dapat mengatur tentang penyiaran dalam bagian kedua kegiatan penyelenggaraan penyiaran. Pada Pasal 1 angka 13 UndangUndang Nomor 32 Tahun 2002 tentang Penyiaran (UU Penyiaran), menjelaskan bahwa Komisi Penyiaran Indonesia (KPI) merupakan sebuah lembaga negara yang bersifat independen yang ada di pusat dan di daerah yang mana tugas dan wewenangnya diatur dalam undang-undang sebagai wujud peran serta masyarakat di bidang penyiaran.

Berkaitan dengan hal tersebut KPI memiliki wewenang untuk dapat melakukan penetapan terhadap standar program siaran, berupa menyusun sebuah peraturan serta menetapkan pedoman perilaku penyiaran, melakukan pengawasan terhadap pelaksanaan peraturan dan pedoman perilaku penyiaran beserta dengan standar program siaran, dapat memberikan sanksi terhadap pelanggaran peraturan dan pedoman perilaku sebuah penyiaran serta standar program siaran, dapat melakukan koordinasi dan/atau kerjasama dengan peme-rintah, lembaga penyiaran dan masyarakat.

Selanjutya untuk tingkat daerah di atur di dalam Pasal 8 ayat (1) UU Penyiaran yaitu menyatakan bahwa Komisi Penyiaran Daerah (KPID) merupakan Lembaga sebagai wujud peran serta oleh masyarakat yang berfungsi mewadahi aspirasi masyarakat serta dapat mewakili kepentingan masyarakat akan penyiaran, selanjutnya pada ayat (2) huruf c menyebutkan bahwa KPID mengawasi pelaksanaan peraturan dan pedoman perilaku penyiaran serta standar program siaran. Berkaitan dengan dasar negara Republik Indonesia Pasal 2 UU Penyiaran menjelaskan bahwa penyiaran diselenggarakan berdasarkan Pancasila dan Undang-Undang Dasar Negara Republik Indonesia Tahun 1945 dengan asas manfaat, adil dan merata, kepastian hukum, keamanan, keberagaman, kemitraan, etika, kemandirian, kebebasan dan tanggung jawab. 
Berkaca pada sejarah Indonesia semenjak era reformasi tahun 1998 dunia penyiaran Indonesia merupakan media yang memiliki fungsi sebagai transformasi informasi, pendidikan dan sebagai media hiburan yang menjadi pilihan oleh masyarakat. Seiring dengan perkembanggannya saat ini televisi bukanlah lagi menjadi barang mewah dan jika kita amati stasiun televisi saat ini tidak lagi di dominasi oleh perusahaan-perusahaan besar. Siaran televisi saat ini merupakan sebuah media komunikasi massa dengan media dengar pandang, yang dapat menyalurkan sebuah gagasan serta informasi dalam bentuk gambar dan suara secara umum, yang mana di dalam siaran televisi memiliki sebuah program yang teratur dan berkesinambungan. ${ }^{1}$ Yang mana program yang berkesinambungan ini seharusnya memiliki muatan pendidikan dan informasi yang baik untuk masyarakat yang ada di Indonesia, perkembangan stasiun televisi lokal ikut menyemarakkan dunia pertelevisian tanah air di mulai dari tahun $2000 .^{2}$ Adapun televisi lokal yang ada di Provinsi Jambi yaitu, Jambi TV, Jek TV, Bungo TV, Tanjabbar TV dan TVRI Jambi.

Pada setiap daerah pastilah memiliki visi pembangunan untuk dapat menjadikan daerahnya maju dan berkembang sesuai dengan kebutuhan masyarakat di daerahnya masing-masing. ${ }^{3}$ Televisi lokal yang merupakan penyiaran televisi daerah, diharapkan untuk mampu melakukan penerjemahkan dan untuk dapat menyukseskan amanah otonomi daerah dengan mengembangkan program-program yang positif berbasis pada kearifan lokal daerah. Paket tayangan yang memiliki materikan budaya, pariwisata, sosial, ekonomi dan memiliki unsur kedaerahan menjadi suatu keharusan bagi seluruh lapisan masyarakat dalam upaya mengoptimalisasi pembangunan daerah. Sehingga dengan kehadiran televisi lokal, menjadi solusi penting untuk hal tersebut. ${ }^{4}$ Televisi lokal saat ini merupakan suatu asset yang tentunya harus dapat dimaksimalkan fungsi dan perannya untuk dapat mengembangkan sebuah sistem siaran lokal yang tentunya harus dapat memiliki kualitas di dalam sistem penyiaran dan program-programnya.

Hal tersebut dijelaskan pula dalam Pasal 3 UU Penyiaran yang menyebutkan bahwa penyiaran diselenggarakan dengan tujuan untuk dapat memperkukuh integrasi nasional, terbinanya watak dan jati diri bangsa yang beriman dan bertakwa, dapat mencerdaskan kehidupan bangsa, memajukan kesejahteraan umum dalam rangka membangun masyarakat yang mandiri, demokratis, adil dan sejahtera, serta dapat menumbuhkan industri penyiaran Indonesia. Selanjutnnya pada Pasal 4 menyatakan bahwa penyiaran sebagai sebuah alat/media komunikasi massa yang mempunyai fungsi sebagai media informasi, pendidikan, hiburan yang sehat, kontrol dan perekat sosial.

Dengan adanya program-program dan tayangan yang berkualitas maka akan memberikan transfer pengetahuan dan ilmu yang baik kepada penonton yang menyaksikan program dari suatu stasiun televisi tersebut yang mana pada saat ini siaran/program tersebut dapat memberikan pengaruh yang sangat besar untuk dapat membentuk opini publik bahkan mengenai pola perilaku keseharian masyarakat. Hal tersebut terjadi dikarenakan pada era liberalisasi informasi saat ini, media penyiaran menjadi salah satu sumber pijakan utama masyarakat di dalam menggali sebuah informasi.

Adapun sebuah tujuan dengan dilakukannya pengawasan adalah untuk dapat mendorong sebuah lembaga penyiaran untuk dapat menjalankan fungsi penyiaran yang pastinya harus mendidik, memberikan sebuah informasi yang sehat, hiburan yang bermanfaat, mampu melakukan perekat sosial dan kontrol sosial dan semua hal tersbut pastilah membutuhkan kontrol. Kontrol atas kebebasan informasi adalah dengan melakukan mekanisme pengawasan terhadap isi dari sebuah program/siaran. Pada tataran ini maka sesuatu hal yang dilakukan dalam penyiaran haruslah sesuai dengan etika penyiaran dan tidak menyalahi aturan perundang-undangan yang berlaku.

Dengan lahirnya Undang-Undang Nomor 32 Tahun 2002 tentang Penyiaran, dapat disimpulkan 2 (dua) hal, pertama mengenai pengelolaan sistem penyiaran harus memiliki asas bebas dari berbagai kepentingan dikarenakan penyiaran merupakan suatu ranah publik dan digunakan sebesar-besarnya untuk kepentingan publik. Kedua adalah sebuah semangat untuk menguatkan entitas lokal dalam semangat otonomi daerah dengan pemberlakuan sistem siaran berjaringan. Berdasarkan pendahuan tersebut maka artikel ini akan membahas mengenai kondisi siaran televisi lokal di Provinsi Jambi dan mengenai strategi pengawasan siaran televisi lokal di Provinsi Jambi oleh KPID.

\section{METODE}

Metode yang di gunaka dalam artikel ilmiah ini adalah metode penelitian yuridis empiris yang mana dilakukan penelitian terhadap studi kasus yang kemudian membahasnya dengan menggunakan bahan bacaan yang diperoleh dari berbagai sumber. Penelitian yang meneliti kaidah atau aturan hukum sebagai suatu bangunan sistem yang terkait dengan suatu peristiwa hukum. Dalam hal ini penulis meneliti bagaimana peran KPID dalam pengawasan penyiaran di Provinsi Jambi. Bahan hukum yang digunakan terdiri dari bahan hukum primer yakni perundang-undangan terkait yaitu Undang-Undang Dasar Negara Republik Indonesia 1945, Undang-Undang Republik Indonesia Nomor 40 Tahun

${ }^{1}$ Danrivanto Budhijanto, Hukum Telekomunikasi, Siaran \& Teknologi Informasi Regulasi \& Konvergensi, (Bandung: PT Refika Aditama, 2010), hlm. 79.

${ }^{2}$ KS. Usman, Television News Reporting and Writing, (Bogor: Penerbit Ghalia Indonesia, 2009), hlm. 1.

3 Yantos, "Peranan Lembaga Penyiaran Publik Lokal Dalam Mendukung Pemerintah Daerah". Jurnal Risalah, No.2, Vol.26, (2015), hlm. 95.

4 Akibu Rifka S, "Implementasi Kebijakan Perizinan Penyiaran Televisi Lokal di Provinsi Gorontalo", Jurnal Ilmu Administrasi, Vol.4, No.2, (2015), hlm. 1. 
1999 tentang Pers, UU Penyiaran, Undang-Undang Republik Indoneisa Nomor 14 Tahun 2008 tentang Keterbukaan Informasi Publik Pedoman Perilaku Penyiaran (P3) dan Standar Program Siaran (SPS) dan Peraturan Komisi Penyiaran Indonesia Nomor 01/P/Kpi/03/2012 Tentang Pedoman Perilaku Penyiaran.

\section{HASIL DAN PEMBAHASAN}

\section{Kondisi Siaran Televisi Lokal di Provinsi Jambi}

Berdasarkan data yang terdapat di KPID Provinsi Jambi, terdapat beberapa Televisi yang beroperasi di Provinsi Jambi yakni sebagai berikut:

1. Kota Jambi dan sekitarnya

\section{UHF}

Indosiar - PT. Indosiar Jambi Televisi

Asal: Jakarta

Konten lokal: Indosiar (suplai)

Durasi lokal: hingga 95 menit/hari, Senin-minggu

Lokasi kantor/pemancar: Lorong Kenali Jaya RT. 015/01, Kota Jambi

27 UHF

Jambi TV - PT. Jambi Televisi

Asal: Jambi

Jaringan: jawapos tv

Konten lokal: Jambi TV (produksi lokal + blocking time)

Durasi lokal: hingga 16 jam/hari, Senin-minggu

Lokasi kantor/pemancar: Kompleks Graha Pena Jambi Ekspres, Jl. Pattimura km.8 No. 35, Kenali Besar, Kota Jambi

Laman web: http://stream.jambitv.net/ (live streaming)

\section{UHF}

Trans TV_PT. Trans TV Jambi Lampung

Asal: Jakarta

Konten lokal: Trans TV (suplai)

Durasi lokal: hingga 125 menit/hari, Senin-minggu

Lokasi kantor/pemancar: Jl. Pattimura RT. 04 Kel. Kenali Besar Kotabaru Jambi

31 UHF

Global TV - PT. GTV Delapan

Asal: Jakarta

Konten lokal: -

Durasi lokal: hingga 5 menit/hari, Senin-minggu

Lokasi kantor/pemancar: Pemancar RCTI-SCTV, Jl. Pattimura RT. 08 Kel. Kenali Besar Kotabaru Jambi

33 UHF

RCTI-PT. RCTI Sebelas Jambi

Asal: Jakarta

Konten lokal: -

Durasi lokal: hingga 5 menit/hari, Senin-minggu

Lokasi kantor/pemancar: Pemancar RCTI-SCTV, Jl. Pattimura RT. 08 Kel. Kenali Besar Kotabaru Jambi

35 UHF

SCTV - PT. Surya Citra Ceria

Asal: Jakarta

Konten lokal: SCTV (suplai)

Durasi lokal: hingga 95 menit/hari, Senin-minggu

Lokasi kantor/pemancar: Pemancar RCTI-SCTV, Jl. Pattimura RT. 08 Kel. Kenali Besar Kotabaru Jambi

37 UHF

Metro TV - PT. Media Televisi Jambi

Asal: Jakarta

Konten lokal: Metro TV (suplai + produksi lokal)

Durasi lokal: hingga 2 jam/hari, Senin-Minggu

Lokasi kantor/pemancar: -

41 UHF

Trans|7-PT. Trans 7 Bengkulu Jambi

Asal: Jakarta 
Konten lokal: Trans|7 (suplai)

Durasi lokal: hingga 125 menit/hari, Senin-minggu

Lokasi pemancar: Jl. Pattimura RT. 04 Kel. Kenali Besar Kotabaru Jambi

45 UHF (analog)/44 UHF (digital)

TVRI-LPP TVRI Stasiun Jambi

Asal: Jakarta

Konten lokal: TVRI Jambi (produksi lokal)

Durasi lokal: 4 jam/hari (terestrial)/hingga 24 jam/hari (satelit), Senin-minggu

Lokasi kantor/pemancar: Jl. Kapt. A. Hasan No. 1 Telanaipura Kota Jambi

47 UHF

Kompas TV - PT. Batanghari Televisi Indonesia

Asal: Jakarta

Konten lokal: Produksi lokal dan relay Kompas TV Palembang

Durasi lokal: 155 menit/hari, Senin-Minggu

Lokasi kantor: Jl. Hayam Wuruk No. 38-40 RT. 20 Kel. Jelutung Kec. Jelutung, Kota Jambi

49 UHF

Jek TV - PT. Jambi Ekspres Televisi

Asal: Jambi

Jaringan: jawapos tv

Konten lokal: Jambi (produksi lokal + blocking time)

Durasi lokal: hingga 15 jam/hari, Senin-minggu

Lokasi kantor/pemancar: Kompleks Graha Pena Jambi Ekspres, Jl. Pattimura km.8 No. 35, Kenali Besar, Kota

Jambi

Laman web: http://jektv.co.id/

\section{UHF}

antv-PT. Cakrawala Andalas Televisi Pontianak dan Jambi

Asal: Jakarta

Konten lokal: -

Durasi lokal: -

Lokasi kantor/pemancar: Pemancar RRI Mendalo Darat, Jl. Lintas Jambi-Muaro Bulian km. 13 (samping Citra Raya City) Desa Mendalo Darat Kab. Muaro Jambi

54 UHF

rtv-PT. Rajawali Televisi Jambi

Asal: Jakarta

Konten lokal: rtv (suplai)

Durasi lokal: hingga 2 jam/hari, Senin-Minggu

Lokasi pemancar: Kompleks Graha Pena Jambi Ekspres, Jl. Pattimura km.8 No. 35, Kenali Besar, Kota Jambi

56 UHF

iNews TV - PT. Semesta Sumatra Televisi

Asal: Jakarta

Konten lokal: MNC News Network (suplai)

Durasi lokal: 125 menit/hari (Senin-Jumat)/95 menit/hari (Sabtu-Minggu)

Lokasi kantor/pemancar: Pemancar RCTI-SCTV, Jl. Pattimura RT. 08 Kel. Kenali Besar Kotabaru Jambi

59 UHF

NET. - PT. Mitra Televisi Kota Jambi

Asal: Jakarta

Konten lokal: NET. (suplai)

Durasi lokal: 2 jam/hari, Senin-minggu

Lokasi pemancar: Kompleks TVRI Jambi, Jl. Kapt. A. Hasan No. 1 Telanaipura Kota Jambi

2. Kab. Bungo dan sekitarnya

40 UHF

Bungo TV - PT. Bungo Media Televisi

Asal: Bungo

Jaringan: jawapos tv

Konten lokal: Bungo (produksi lokal + blocking time)

Durasi lokal: hingga 15 jam/hari, Senin-minggu 
Lokasi kantor/pemancar: Jl. Dipenegoro No. 09 Kel. Pasir Putih Kec. Rimbo Tengah Kab. Bungo

Laman web: http://stream.bungotv.co.id/ (live streaming)

3. Kab. Tanjung Jabung Barat dan sekitarnya

48 UHF

Tungkal TV_L LPPL Tungkal Televisi Kabupaten Tanjung Jabung Barat

Asal: Tanjung Jabung Barat

Lokasi kantor: Jl. Letkol Polisi Toegino No. 06 Kuala Tungkal-36513

Laman web: http://lppltungkaltv.pekku.com/

4. Kota Sungai Penuh dan sekitarnya

\section{UHF}

SPTV_LPPL Televisi Sungai Penuh dan Sakti Alam Kerinci

Asal: Sungai Penuh

Durasi: hingga 4 jam/hari

Lokasi Kantor/pemancar: Jl. Pancasila No. 98 Desa Lawang Agung Kota Sungai Penuh.

Berdasarkan data di atas, maka pada dasarnya televisi yang beroperasi di daerah Provinsi Jambi terdiri dari dua, yaitu Televisi Nasional yang memiliki Studio dan berkedudukan di wilayah Jambi dengan memberikan jadwal untuk siaran lokal Jambi dan Televisi Lokal yang berkedudukan di Provinsi Jambi yang menyiarkan secara penuh waktu siaran lokal Jambi. Dengan demikian maka isi siaran Televisi Lokal Jambi sama-sama mempunyai peluang untuk melakukan pelanggaran atas peraturan KPI tentang P3SPS. Berdasarkan data di KPID Provinsi Jambi dalam tahun 2016 banyak sekali pelanggaran terutama pada saat pelaksanaan Pemilihan Kepala Daerah. Selain itu pada tahun 2017 terhitung bulan Oktober terdapat 12 Pelanggaran yang telah diberikan sanksi teguran, yaitu:

Tabel 1. Data Pelanggaran Isi siaran Televisi Lokal Tahun 2017

\begin{tabular}{|c|c|c|c|}
\hline No & Televisi/Tgl & Program & Sanksi/Pasal \\
\hline 1. & Jek TV / Februari & Iklan Kapsul Stamina Jian sen Kap & $\begin{array}{l}\text { Teguran tertulis pertama/Pasal } 43 \text {, pasal } 37 \text { ayat(4) } \\
\text { huruf e dan Pasal } 59 \text { ayat ( } 3 \text { ) }\end{array}$ \\
\hline 2. & Jek TV/ Februari & Berita Sekitar Jambi & $\begin{array}{l}\text { Teguran Tertulis/ P3 Pasal } 18 \text { dan Pasal 43, SPS Pasal } \\
26 \text { ayat (1) dan Pasal } 27 \text { ayat (2) }\end{array}$ \\
\hline 3. & Jambi TV/ Februari & Berita Detak Jambi & $\begin{array}{l}\text { Teguran Tertulis/ SPS Pasal } 15 \text { ayat (1) dan (30, pasal } \\
43 \text { huruf g }\end{array}$ \\
\hline 4. & Jek TV/ Februari & Iklan kapsul Stamina Jian Sen Kap & $\begin{array}{l}\text { Teguran tertulis Kedua/Pasal } 43 \text {, pasal } 37 \text { ayat(4) huruf } \\
\text { e dan Pasal } 59 \text { ayat ( } 3 \text { ) }\end{array}$ \\
\hline 5. & Jek TV/ Februari & Klafikasi Lembaga Penyiaran & Klarifikasi \\
\hline 6. & Jek TV/Maret & Iklan kapsul Stamina Jian Sen Kap & Mengundang Jek Tv untuk Klarifikasi Acara Tersebut \\
\hline 7. & Jek TV/ April & RM Jek TV & $\begin{array}{l}\text { Teguran/ SPS Pasal 9, Pasal } 15 \text { ayat (1),pasal } 37 \text { (4) } \\
\text { huruf a. }\end{array}$ \\
\hline 8. & Jambi TV/ April & Ado Ado Bae & Teguran/SPS pasal 23 huruf a. \\
\hline 9. & Jambi TV/ April & Detak Jambi & Teguran/SPS Pasal 26 ayat (1) \\
\hline 10. & TVRI Jambi/april & Melangun Suku Anak Dalam & $\begin{array}{l}\text { Teguran/SPS Pasal } 18 \text { huruf h dan j, SPS Pasal } 33 \text { ayat } \\
\text { (10 huruf d }\end{array}$ \\
\hline 11. & Jambi TV/ Mei & Detak Jambi & Teguran/SPS Pasal 26 ayat (1) \\
\hline 12. & Jambi TV/ Mei & FILM (cinema 27) & Teguran/SPS Pasal 23 huruf a \\
\hline
\end{tabular}

Sumber: KPID Provinsi Jambi

Berdasarkan tabel di atas menunjukkan bahwa 3 (tiga) Televisi Lokal yang menjadi objek fokus pengawasan KPID Jambi sama-sama melakukan pelanggaran atas isi siaran. Bahkan pelanggaran tersebut merata pada program iklan, berita bahkan cinema. Sedangkan televisi lain selain TV Jambi, Jek TV dan TVRI Jambi justru tidak ada data pelanggaran di KPID Jambi karena tidak dilakukan pengawasan oleh KPID Jambi. Padahal televisi-televisi tersebut ada jadwal tanyang dengan siaran lokal Jambi.

\section{Strategi Pengawasan Siaran Televisi Lokal di Provinsi Jambi}

Berdasarkan hasil wawancara dengan ketua KPID Provinsi Jambi terkait dengan pengawasan Televisi Lokal di Jambi pada Pedoman Prilaku Penyiaran. Dijelaskan oleh Arif Usman ketua KPID Provinsi Jambi "KPID mengawasi dengan cara monitoring selama 12 jam siaran, dengan adanya proses monitoring KPID bisa melihat program ataupun siaran yang melakukan pelanggaran Pedoman Prilaku Penyiaran, pada saat diketahui adanya pelanggaran Pedoman Prilaku Penyiaran, operator melaporkan ke bagian verifikasi dari verifikasi masuk ke bagian analis dari analis di laporkan kebagian pengawasan isi siaran melalui koordinator bidang, kemudian di evaluasi. selanjutnya dipastikan ada pelanggaran atau tidak dari laporan yang dilakukan oleh bagian monitoring. Ketika dipastikan ada pelanggaran 
maka pelanggaran tersebut di naikan ke tingkat pleno, di pleno di putuskan apakah melanggar undang-undang penyiaran atau tidak.

Selain itu berkaitan dengan pelanggaran yang dilakukan oleh Televisi Lokal sesuai dengan tingkatannya, sebagaimana dikatakan oleh Muhammad Abdi Koordinator bidang pengawas isi siaran Komisi Penyiaran Indonesia Daerah Provinsi Jambi, Pelanggaran tersebut memiliki 3 (tiga) kategori, yaitu:

1. Kategori Merah yakni pelanggaran berat;

2. Kategori Kuning yakni masih bisa diperbaiki; dan

3. Kategori Hijau yakni tidak ada pelanggaran.

Pada kasus tersebut selanjutnya akan di lakukan pleno dan dari hasil pleno tersebut akan memutuskan apabila terjadi sebuah pelanggaran, adapun terkait beberapa keputasan terhadap pelanggaran tersebut KPID akan memutuskan hal-hal sebagai berikut:

1. Peringatan tertulis;

2. Pengurangan durasi;

3. Pembekuan acara; dan

4. Pencabutan izin lembaga penyiaran yang melanggar penyiaran itu.

Selanjutnya dalam prakteknya sampai saat ini belum ada Televisi Lokal yang melakukan pelanggaran berat, hanya ada pelanggaran yang terkait dengan format pembagian siaran yang tidak ada menampilkan kode peruntukan siaran pada layar Televisi tersebut, isi iklan yang salah dan azan dimanfaatkan untuk iklan". Sedangkan terkait dengan data-data pelanggaran yang dilakukan oleh Televisi Lokal, dikatakan oleh Ketua KPID Provinsi Jambi "sampai saat ada beberapa pelanggaran yang sudah diberikan sanksi yakni dalam bentuk teguran yakni TVRI Jambi terkait dengan siaran yang tidak menampilkan kriteria siaran".

Kemudian terkait dengan fokus pengawasan yang dilakukan oleh KPID Provinsi jambi, dikatakan oleh Koordinator bidang isi siaran KPID Provinsi Jambi "KPID selalu melakukan sosialisasi tetapi setiap lembaga penyiaran itu SDM nya berbeda-beda. Dan disitulah yang membedakan lembaga penyian dengan lembaga penyiara lainya, ada yang mematuhi Pedoman Prilaku Penyiaran dan ada yang belum mematuhi Pedoman Prilaku Penyiaran. Dalam hal ini KPID di Provinsi Jambi setidaknya melakukan pengawasan atas Televisi Lokal yang ada di Jambi, yaitu TVRI Jambi, Jambi TV, Jek TV dan untuk Televisi Lokal yang ada di Kabupaten KPID Jambi belum mempunyai perangkat untuk melakukan pengawasan.

KPID Provinsi Jambi telah melakukan pengawasan akan tetapi tidak secara terencana dan terinci. Hal ini didasari bahwa KPID Provinsi Jambi tidak melaksanakan pengawasan berdasarkan pada potensi kerawanan pelanggaran Pedoman Perilaku Penyiaran sebagai dasar fokus pengawasan. Dalam hal ini pengawasan lebih diberikan pengawasan penuh dan menyeluruh tidak pada fokusnya pengawasan. Namun secara tataran teori seharusnya lembaga pengawas televisi terlebih dahulu membuat potensi pelanggaran program siaran sebagai fokus pegawasan. Selain itu dapat juga dikatakan bahwa KPID Provinsi Jambi menggunakan strategi pengawasan televisi lokal di Provinsi Jambi dengan cara monotoring siaran, menunggu laporan dari masyarakat sedangkan Televisi Lokal yang berada di Luar Kota Jambi dilakukan dengan strategi membentuk relawan pengawas yang ada di Kabupaten/kota yang terdapat televisi lokal.

Seharusnya perkembangan dari teknologi komunikasi harus dapat membuat produk komunikasi memiliki sebuah standarisasi di dalam pengelolaannya. Standarisasi produk tersebut harus memiliki dampak yang tak terelakkan dari sebuah industrialiasi media, yang memiliki mekanisasi, urbanisasi dan nantinya berujung pada redistribusi pendapatan. ${ }^{5}$ Selanjutnya berkaitan dengan kepemilikan yang telah dipegang serta berkaitan dengan pengendalian media yang dapat dilakukan dan akan mempengaruhi isi media serta isi media itu sendiri juga dapat menentukan pengaruh media dalam masyarakat. ${ }^{6}$ KPI merupakan lembaga yang bersifat independen yang di bentuk melalui UU Penyiaran.

Kemudian KPID Provinsi Jambi sudah ada memberikan sanksi atas pelanggaran yang dilakukan oleh Televisi Lokal Jambi, dikatakan oleh Ketua KPID Provinsi Jambi "televisi yang ada di Jambi sudah ada sanksi diberikan, namun masih dalam bentuk surat teguran". Dalam strategi pengawasan yang dilakukan oleh KPID Provinsi Jambi masyarakat juga ada yang melaporkan atas pelanggaran Pedoman Perilaku Penyiaran tersebut, dikatakan oleh Ketua KPID Provinsi Jambi "ada masyarakat yang melaporkan pelanggaran oleh Televisi Lokal pada umum pada saat pemilihan umum atau pemilihan kepala daerah". jadi Strategi pengawasan oleh KPID Provinsi Jambi terhadap televisi lokal di Jambi masih bersifat reaktif atas apa yang terjadi dan terpantau oleh KPID Provinsi Jambi.

Berdasarkan pembahasan di atas maka teori efektifitas hukum sangat cocok digunakan dalam artikel ilmiah ini sebab teori ini mengkaji dan menganalisis tentang keberhasilan dan kegagalan dan faktor yang mempengaruhi dalam

\footnotetext{
${ }^{5}$ Sucahya Media, “Teknologi Komunikasi dan Massa”, Jurnal Komunikasi, Vol.2, No.1, (2013), hlm. 8.

${ }^{6}$ J. Severin Werner dan Jr. W. Tankard James, Teori Komunikasi, (Jakarta: Kencana Prenada Media Grup 2011 ), hlm. 373.
} 
sebuah pelaksanaan dan penerapan hukum dikarenakan jika di kaji dari keberhasilan dalam pelaksanaan hukum sudah sangat mengikat dan memiliki kekuatan hukum tetap serta di patuhi oleh semua lembaga siaran yang ada di Provinsi Jambi.

\section{SIMPULAN}

Lembaga Independen terdiri dari KPI Pusat dan KPID di daerah yang tugasnya bersifat koordinatif, kebijakan secara nasional tersebut di tentukan oleh KPI sedangkan pelaksanaan berada pada tingkat Provinsi menjadi cakupan KPID berkaitan dengan isi siaran Televisi Lokal Jambi sama-sama mempunyai peluang untuk melakukan pelanggaran atas peraturan KPI tentang P3SPS. Berdasarkan data di KPID Provinsi Jambi dalam tahun 2016 banyak sekali pelanggaran terutama pada saat pelaksanaan Pemilihan Kepala Daerah. Selain itu pada tahun 2017 terhitung bulan Oktober terdapat 12 Pelanggaran yang telah diberikan sanksi teguran. Pelanggaran tersebut merata pada program iklan, berita bahkan cinema. Sedangkan televisi lain selain TV Jambi, Jek TV dan TVRI Jambi justru tidak ada data pelanggaran di KPID Jambi karena tidak dilakukan pengawasan oleh KPID Jambi. Padahal Televisi-televisi tersebut ada jadwal tanyang dengan siaran lokal Jambi.

KPID Provinsi Jambi menggunakan strategi pengawasan televisi lokal di Provinsi Jambi dengan cara monotoring siaran, menunggu laporan dari masyarakat sedangkan Televisi Lokal yang berada di Luar Kota Jambi dilakukan dengan strategi membentuk relawan pengawas yang ada di Kabupaten/kota yang terdapat televisi lokal. Sehingga pada dasarnya strategi pengawasan oleh KPID Provinsi Jambi terhadap televisi lokal di Jambi masih bersifat reaktif atas apa yang terjadi dan terpantau oleh KPID Provinsi Jambi.

\section{DAFTAR PUSTAKA}

\section{Buku}

Danrivanto Budhijanto. Hukum Telekomunikasi, Siaran \& Teknologi Informasi Regulasi \& Konvergensi. Bandung: PT Refika Aditama, 2010.

J. Severin Werner dan Jr. W. Tankard James. Teori Komunikasi. Jakarta: Kencana Prenada Media Grup, 2011.

KS. Usman. Television News Reporting and Writing. Bogor: Penerbit Ghalia Indonesia, 2009.

\section{Jurnal}

Akibu Rifka S. "Implementasi Kebijakan Perizinan Penyiaran Televisi Lokal di Provinsi Gorontalo". Jurnal Ilmu Administrasi. Vol.4, No.2, (2015): 1.

Sucahya Media. "Teknologi Komunikasi dan Massa". Jurnal Komunikasi. Vol.2, No.1, (2013): 8.

Yantos. "Peranan Lembaga Penyiaran Publik Lokal Dalam Mendukung Pemerintah Daerah". Jurnal Risalah. No.2, Vol.26, (2015): 95.

\section{Peraturan Perundang-Undangan}

Undang-Undang Dasar Negara Republik Indonesia 1945

Undang-Undang Republik Indonesia Nomor 40 Tahun 1999 Tentang Pers

Undang-Undang Republik Indonesia Nomor 32 Tahun 2002 Tentang Penyiaran.

Undang-Undang Republik Indoneisa Nomor 14 Tahun 2008 Tentang Keterbukaan Informasi Publik Pedoman Perilaku Penyiaran (P3) dan Standar Program Siaran (SPS).

Peraturan Komisi Penyiaran Indonesia Nomor 01/P/Kpi/03/2012 Tentang Pedoman Perilaku Penyiaran. 